\title{
Vocational High School Students Entrepreneurship: The Success of Family or School Education..?
}

\author{
Arum Biruli Walidaini \\ Agung Wirnarno \\ Program Studi Pendidikan Tata Niaga Universitas Negeri Malang \\ E-mail: agung.winarno.fe@um.ac.id
}

\begin{abstract}
Purpose of this research is to - determine entrepreneur attitude of SMK students that have entrepreneurship, - determine role of eductaion in family also the role of eduction in school. Approch of that type used is qualitative. Research object was SMK students had been doing entrepreneur while Wadi. Informant in this research were students, the student's parent, teacher of entrepreneur and headmaster. Data collecting using deep interview technique, observation and documentation also attitude test. The research result shows that entreprenuership attitude of students include high category, education of family has important role to build entrepreneurship attitude in terms of involving children in their business, the role of school limited in supporting development of student's knowledge.
\end{abstract}

Keywords: Entrepreneurship SMK Students, Family Education, School Education

Entrepreneur is a courageous people who take the risks to open a business on various occasions by taking advantage of opportunities (Ferreira, et al, 2017). Entrepreneurship can be done by someone who has had the job, already have a job, or someone who is taking education (Maresch, et al, 2014). Become a unique phenomenon if entrepeneur is done by students who are taking education (Nielsen, et al, 2017) because in general students who are taking education tend to focus by learning (Shirokova, et al, 2016). Entrepreneur has the attitude of independent, confident, and able to bear the risks (Ojala, 2016). Entrepreneurial attitude can be embedded from the form of family entrepreneurship education and education pattern provided by the school, so students have thought to entrepreneurship (Elert, et al, 2015).

Entrepreneurial Education inculcated early on, can prepare students who are skilled in entrepreneurship (Walter, et al, 2015) . Entrepreneurship education can be taught in family or formal school (Collins, et al, 2013). Soemanto (2008:90) stated that the implementation of entrepreneurship education can be done in the family environment, school environment and community environments. Entrepreneurship education in schools should be able to instill the entrepreneurial character of students, such as confidence, initiative, and risk takng (Draycott, et al, 2011). Although it has been pointed that entrepreneurship education in schools are taught the theory rather than the formation of entrepreneurial attitudes (Winarno, 2015). 
In addition to the school and public education, the family also plays an important role in shaping entrepreneurial potential of children (Hussain, et al, 2010) . Treatment and entrepreneurial education given by the family, especially the parents, will have an effect on personality, character, attitude and behavior of children (Akinola, et al, 2014). Parents should prepare and educate children to become entrepreneurs to prepare the children in the future (Hamilton, 2011). Entrepreneurship education should be imparted to the children from birth and then developed in the family environment, this is the role of parents and family to prepare the children in entrepreneurship (Soemanto, 2008:95).

School is a place to learn, practice and provide education to students (Idi, 2011:77) . In school, students are trained and educated to become a skilled people and have a high confidence (Matlay, 2005). In addition, the school should also begin to realize the students to become entrepreneurs (Robinson, et al, 2016). With the teachers as educators and entrepreneurial practices contained in the school, is expected to hone skills and formed a personal student with high confidence (Soemanto, 2008:137).

Entrepreneurship Education in families and school can support students to become entrepreneurs. Kasmir (2006:19 "wirausahawan (entrepreneur) adalah orang yang berjiwa berani mengambil resiko untuk membuka usaha dalam berbagai kesempatan". The courage to take risks in entrepreneurship need to be instilled early on to students (Katz, 2001). The pattern of entrepreneurial education given by the family and the school will be the basic for students to open a business and become a young entrepreneur (Paul, et al, 2011).

Based on the research results, Farida (2014) found that family and school environment had an affects on student's interest in entrepreneurship program marketing expertise in SMKN 1 Turen. Triyani (2016) also found that education support and environmental support have an effect on entrepreneurship interest. From these results show that support the environment, especially the family and the school environment has an effect on the interest of entrepreneurship students. Supporting parents and school that provide sufficient knowledge of entrepreneurial can foster students' entrepreneurial interest (Collins, 2013).

Entrepreneurship is an independent attitude and behaviour that is able to combine elements of inventiveness, taste and intention as well as or able to combine elements of creativity, challenges, hard work and satisfaction to achieve maximum performance so as to provide maximum added value to services, goods and services produced by heeding the joints of people's lives, Sutanto (2002:11). Winarno (2010) mentioned at least someone has the potential to become an entrepreneur if it has advantages in terms of confidence, courage in risk, selfmotivation and leadership. While the entrepreneur are people who are courages take risks to open a business in various occasions, Kasmir (2006:19). In General, entrepreneurs have an entrepreneurship attitude applied when entrepreneurship (Zampetakis, et al, 2017).

Hendro (2011:165) describes the attitude of the entrepreneurs is the attitude that always think positive, have a positive response, future-oriented, not afraid competitors, always curious, always give the best, never give up, and have a strong commitment to achieve goals. Entrepreneurship attitude can be instilled through entrepreneurship education in family and school (Soemanto, 2008:143). 
Family and school Entrepreneurship Education greatly influences the attitude of entrepreneurship students. The cultivation of the values of entrepreneurship in family can provide the basic knowledge tof entrepreneurship to the children (Hoy, 2010). Provisions in the form of values and a strong personal potential should have started from the family, because the role of the family in educating children to become entrepreneurs is very important (Seuneke, 2015). The family has first and foremost obligation and responsibility in educating children, In other words, the family or parents play a role as the foundation of the child's personal development (Hoy, 2010). In addition to the family Schools also take part in preparing students in entrepreneurship. Schools are educational institutions the right to cultivate the attitude of the entrepreneur (Stamboulis, et al, 2014). Entrepreneurship education such as entrepreneurship subjects and entrepreneurship practices in schools can encourage students to engage in entrepreneurship (Woodfield, 2011). The focus of the research is revealing how entrepreneurship attitude of the students who running a business, and the role of education in the family and the education of entrepreneurship in schools.

\section{METHOD}

This type of research is qualitative with case study approach. Key informant is entrepreneurship students, parents of students, teachers of subjects of entrepreneurship and the principal. The attitude of the entrepreneur is measured by the way of thinking, the response to problems, future orientations, attitudes towards competitors, curios, the attitude towards others, durability, and a commitment to entrepreneurship. Checking the validity of the data using a triangulation of source and an extension of the observation. Qualitative data analysis is done interactively and continues in the form reduction of data presentation and verification.

\section{RESULTS \& DISCUSSION}

\section{Results}

Based on the test results obtained information that the attitude of entrepreneurship students in the positive category. This is known from students who already have a positive response attitude, future-oriented, not afraid to competitors, always curious, giving the best to buyer, struggling to sell, and have a strong commitment. The form of the family education in the form of the introduction of entrepreneurial practices either directly and indirectly. Indirectly by the attitude and entrepreneurial actions of parents who applied at the time of entrepreneurship so that students can be imitate and emulate the entrepreneurial attitude of parents. This happens because all students are entrepreneurship turned out to be the profession of his parents are entrepreneurs.

Education directly in the form of providing the support by way of trusting children to open a businesses even provide initial capital and motivate. Parents of students also teach children to have a confident attitude, responsibility, and willing to take a risk. Parents of students have a different types of businesses, but how to 
educate them for entrepreneurship have in common. In contrast to entrepreneurial education at school, students generally get entrepreneurial theory of material on subjects creating craft and entrepreneurship which most emphasis on aspects of production skills. The attitude of students entrepreneurship according to informants of the existence of the theory and practice of entrepreneurship. If further explored the theory given by teachers associated with the formation of the attitude less than the skill. Teachers also give the task to make the practice skills to students, interns are given two times in one semester. Education of school entrepreneurship taught more theory than practice of entrepreneurship to students.

The results of the study also showed that education is being taught in more families contribute in growing attitude of students entrepreneurship than education given in the schools. That is because the parents instill the provision of knowledge and entrepreneurial values directly or indirectly. Parents taught the practice of entrepreneurship, such as when parents provide the initial capital and invite students participate in their efforts. Students help parents business and has joint effort family members. A comparison of how entrepreneurial education in the family and school, as in table 1.

\section{Table 1. Comparison of Entrepreneurship Education in Families and School}

\begin{tabular}{clll}
\hline No. & $\begin{array}{c}\text { Education of } \\
\text { Entrepreneurship }\end{array}$ & \multicolumn{1}{c}{ Family } & \multicolumn{1}{c}{ School } \\
\hline 1. & Capital & $\begin{array}{l}\text { Provide initial } \\
\text { capital assistance }\end{array}$ & not providing the initial capital \\
\hline 2. & $\begin{array}{l}\text { Provision of } \\
\text { entrepreneurship } \\
\text { knowledge }\end{array}$ & $\begin{array}{l}\text { invite students to } \\
\text { participate in } \\
\text { running the } \\
\text { business. }\end{array}$ & $\begin{array}{l}\text { entrepreneurship knowledge to } \\
\text { students in the form of theories on } \\
\text { subjects }\end{array}$ \\
\hline 3. & The values of & $\begin{array}{l}\text { giving motivation, } \\
\text { advice and guidance } \\
\text { entrepreneurship }\end{array}$ & $\begin{array}{l}\text { provide support through school } \\
\text { facilities }\end{array}$ \\
\hline 4. & The practice of & $\begin{array}{l}\text { work directly in the } \\
\text { entrepreneurship } \\
\text { real business world } \\
\text { (production and or } \\
\text { sell) }\end{array}$ & $\begin{array}{l}\text { the limited product sales through } \\
\text { the Bazaar in school }\end{array}$ \\
& &
\end{tabular}

Source: Informant

From table 1 it can be concluded that entrepreneurial education in the family more practice of entrepreneurship to the students. Parents are also indirectly role models and examples for students to run the business through direct practice.

\section{Discussion}

Based on the findings results of research show that, Attitude of Entrepreneurship Students can be categorizedas high. The entrepreneurial spirit are started to appear on the student's self even before entering in Vocational School, entrepreneurial potential indeed can begin to grow in age like that it is 
strengthened by Pruett, et al, (2017). The results of data mining are indeed students always changed the type of its business, on average they have changed business more than twice as long as in the vocational school, it is indicates of the self confidence and attitude to want to take the risk in students and this is corroborated by the findings of Ferreira, et al, (2017) that the key entrepreneurship is high confidence. According to Hendro (2011:165-166) An entrepreneur have to an attitude of always positive thinking, positive response, future oriented, not afraid of competitors, always curious, giving the best to buyer, fight hard, and has a strong commitment. The attitude has been owned by the vocational students be informants.

Family is very important to educate students in entrepreneurship (Hoy, 2010). The parents of students are entrepreneur who has certainly had an entrepreneurial attitude that is applied in business (Hamilton, 2011). The values of the entrepreneur owned by parents of students passed down to his children in order to afford children have the knowledge about the field of entrepreneurship. It is aligned with the theory be delivered by Soemanto (2008:112) namely that parents or families can play a role as the Foundation to prepare the entrepreneur, then one of the requirements that should be owned by parents is its entrepreneurial spirit by parents (Hussain, 2010). With the entrepreneurial spirit that has been owned by parents, then parents will contribute to teaching students to become entrepreneurs (Akinola, 2014).

Ihsan (2011:57) Suggest that "Lingkungan keluarga merupakan lembaga pendidikan yang pertama dan utama karena dalam keluargalah manusia dilahirkan, berkembang menjadi dewasa". Therefore any committed parents will be an example for their children. Parents who have a business will be able to motivate the students to have business (Hussain, 2010). Of the family, too, students learn entrepreneurial attitude that can be applied when their entrepreneurship (Seuneke, 2015).

Parents who are entrepreneurship teach students to help the parents business (Hamilton, 2011) . Students help parents to selling food and stationery. Other students have a business with family, to sell cosmetics and handbags. Entrepreneurial education by way of building the family into a mini company can be learning students on attitude entreprenurship and how to become an entrepreneur (Soemanto, 2008:103). In accordance with the curriculum of 2013 entrepreneurship education in school is compiled in the subject of the craft and entrepreneurship, and that is the teaching staff that Guide the students in understanding entrepreneurship (Rofiah, 2016).

Based on research findings, the teachers teach the knowledge of entrepreneurship that can support attitude of entrepreneurship students (Pruett, et al, 2017). In the research of Elena, et. al., (2013) found that the motivation of students in entrepreneurship can also be obtained from teachers telling illustrations of successful entrepreneurial figures. Teachers pointed out to the students about themselves, which is also an entrepreneur. Teachers not only teach theory about entreprenurship, but teachers also go directly into the business world. In accordance with Soemanto's theory (2008:140) “Untuk mengajarkan teori dan praktek kewirausahaan, guru harus mempunyai sikap statis dan 
dinamis". In addition, the teacher must also have the entrepreneurial attitudes of these things also have done the teacher although in limited instances.

In the learning process that occurs in the classroom, entrepreneurial students are classified as active in learning activities. The practice of entrepreneurship that requires students to make creative skills can help the formation of students attitude this is supported by findings of Hamidi, et al, (2008). The teacher teach students in making skills in order to have students to have an independent attitude and independent by other (Lepito, 2013). Indirectly teachers teach students to have entrepreneurial attitudes (Elena, et al, 2013 However, the practice of entrepreneurship given by teachers is only 2 times in a semester. Limited time only 2 hours of lessons are also restricting teachers to provide wider entrepreneurship to students.

From the results of research students have the attitude of entrepreneurship. That is because the parents profession students has indirectly provided teaching on entrepreneurial attitudes, such as the attitude of positive thinking in risk, the positive response, passion and hard work and it is important for potential entrepreneurs (Ojala, 2016). According to Soemanto (2008:143) learning outcomes to be achieved by students include moral values, entrepreneurial mental attitude, entrepreneurial skills. It is not fully in the process of teaching and learning activities in vocational school. Even though the supposed moral values, entrepreneurial mental attitude and skills should be taught by the teacher to the students (Lepisto, 2013).

The function of teaching in schools, according to Meresch, et al, (2014), Elert, et al, (2015) is to give motivation to students for entrepreneurship at once practice (Matlay, 2012). But in practice, in the school's own entrepreneurial practice activities done only twice in a semester, while school programs such as the Bazaar is done 3 times a year. The school imparts a more entrepreneurial form of theory than entrepreneurial practice.

Related research results that the family environment plays a major role in the formation of entreprenurial attitudes of a person supported by Soemanto statement (2008:90) which States that the implementation of entrepreneurship education can be done in the family environment as the first environment to educate entrepreneurs. The family as a first and main responsibility the implementation of entrepreneurship education. Entrepreneurship Education can also be done in the school environment as a formal educational environments to complete the complement entrepreneurship, because the school as the rensposible education of students entrepreneurship.

This is in accordance with research findings that entrepreneurial education inculcated by families and school contribute to cultivating attitude of students entrepreneurship (Farida, 2014). But the greatest contribution is owned by the students, that is the provision of knowledge from the family of students who are directly and indirectly give the values of entrepreneurship attitude to students. The capacity of Entrepreneurial learning time between at home and in schools also have an effect on the attitude of students entrepreneurship. Students spend more time at home, every day the students get entrepreneurship education in the family because students are also involved in the parent's business (Hoy, 2010). While the entrepreneurial learning in school is done 2 hours per week. 
In schools, entrepreneurship theory is more often gained by students than in practice. Teachers provide entrepreneurial values and provision of knowledge to students (Elena, 2013), but for the practice of entrepreneurship is still not optimally. Entrepreneurship education is taught in schools also contribute in fostering attitude of students entrepreneurship, but the greaterr the contribution given by the family to the students.

\section{CONCLUSION \& SUGGESTIONS}

\section{Conclusion}

Vocational students who have entrepreneurship have high entrepreneurial attitude based on the dimension of way of thinking, durability, views of risk and commitment. That attitude are largely derived from the education in families whose parents work as entrepreneurs and support their children to run a business. While the limited school education support in terms of adding insights and skills.

\section{Suggestions}

The suggestions given to schools is the need to have data about students whose parents are entrepreneurs to get special coaching, and if required can work with parents to develop the potential of students. While the entrepreneurship education in schools need multiply opportunities to practice to students as well as encourage students to open businesses in any form outside of school hours are available.

\section{REFERENCES}

Arikunto, S. 2010. Prosedur Penelitian Suatu Pendekatan Praktik. Edisi Revisi 2010. Jakarta: PT Rineka Cipta.

Evaliana, Y. 2015. Pengaruh Efikasi Diri dan Lingkungan Keluarga Terhadap Minat Berwirausaha Siswa. Jurnal Pendidikan Bisnis dan Manajemen, (Online), 1 (1): 61-70, (http://journal.um.ac.id/index.php/jpbm/article/view/5034), diakses 25 November 2016.

Collins, L., Seaman, C., Graham, S \& Stepek, M. 2013. The Future of Family Business Education in UK Bussiness Schools. Education+Training, (Online), 55(4): 445460, (http://emeraldinsight.com/doi/full/10.1108/00400911311326063), diakses 11 Mei 2017.

Draycott, M., Rae, D. Enterprise Education in Schools and The Role of Competency Framework. International Journal of Entrepreneurial Behavior \& Research, (Online), 17 (2): 127-145, (http://emeraldinsight.com/doi/abs/10.1108/13552551111114905), diakses 11 Mei 2017. 
Elena, R \& Ruskovaara, E. 2013. Teacher Implementing Entrepreneur Education: Classroom Practices. Education+Training, (Online), 55(2): 204-216, (http://emeraldinsight.com/doi/full/10.1108/00400911311304832), diakses 11 Mei 2017.

Elert, K., Andresson., Wennberg, K. 2015. The Impact of Entrepreneurship Education in High School on Long Term Entrepreneurial Performance. Journal of Economic Behavior \& Organization, (Online), 111: 209-223, (http://www.sciencedirect.com/science/article/pii/S0167268114003333), diakses 11 Mei 2017.

Farida, R. 2014. Pengaruh Persepsi Siswa Tentang Lingkungan Keluarga dan Sekolah Terhadap Minat Berwirausaha Siswa di SMKN 1 Turen. Skripsi tidak diterbitkan. Malang: Universitas Negeri Malang.

Ferreira, A., Loiola, E., Gondim, S. 2017. Motivations, bussinses planning, and Risk Management. ScienceDirect, (Online), (http://www.sciencedirect.com/science/article/pii/S1809203917300335), diakses 11 Mei 2017.

Hamidi, D.Y., Weenberg, K \& Berglund, H. 2008. Creativity in Entrepreneurship Education. Journal of Small Business and Enterprise Development, (Online), 15 (2): 304-320, (http://emeraldinsight.com/doi/full/10.1108/14626000810871691), diakses 11 Mei 2017

Hamilton, E. 2011. Entrepreneurial Learning in Family Business: A situated Learning Perspective. Journal of Small Business and Enterprise Development, (Online), 18 (1): 8-12, (http://emeraldinsight.com/doi/full/10.1108/14626001111106406), diakses 11 Mei 2017.

Hendro. 2011. Dasar-dasar Kewirausahaan. Jakarta: Erlangga.

Hoy, F. 2010. Team Approaches to Entrepreneurship and Family Bussiness Education. Book Series: Advances in Entrepreneurship, Firm Emergency and Growth, (Online), 12: 349-357, (http://emeraldinsight.com/doi/full/10.1108/S10747540\%282010\%290000012019), diakses 11 Mei 2017.

Hussain, J., Scott, J., Matlay, H. 2010. The Impact of Entrepreneurship Education on Succession in Ethnic Minority Family Firms. Education+Training, (Online), 52 (8): 643-659, http://emeraldinsight.com/doi/full/10.1108/00400911011088962), diakses 11 Mei 2017.

Idi, A. 2011. Sosiologi Pendidikan. Jakarta: PT Raja Grafindo Persada. 
Ihsan, F. 2011. Dasar-dasar Kependidikan. Jakarta: Rineka Cipta.

Lepisto, J. 2013. Teacher Students As Future Entrepreneurship Educators and Learning Facilitators. Education+Training, (Online), 55 (7): 641-653, (http://emeraldinsight.com/doi/full/10.1108/ET-05-2012-0055), diakses 11 Mei 2017.

Maresch, D., Harms, R., Wurm, B. 2014. The Impact of Entrepreneurship Education on The Entrepreneurial Intention of Student in Science and Engineering Versus Bussiness Studies University Programs. Technological Forecasting and Social Change, (Online), 104: 172-179, (http://www.sciencedirect.com/science/article/pii/S004016251500339X), diakses 11 Mei 2017.

Matlay, H. 2005. Entrepreneurship Education in UK Bussiness School: Conceptual, Contextual and Policy Consideration. Journal of Small Business and Enterprise Development, (Online), 12 (4): 627-643, (http://emeraldinsight.com/doi/full/10.1108/14626000510628270), diakses 11 Mei 2017.

Matlay, H. 2012. Theory and Practice in Entrepreneurship Education. Education+Training, (Online), 54 (8), (http://emeraldinsight.com/doi/full/10.1108/et.2012.00454haa.001), diakses 11 Mei 2017.

Nielsen, S.L \& Gartner, W.B. 2017. Am I a Student and or Entrepreneur? Multiple Identities in Student Entrepreneurship. Education+Training (Online), 59 (2): 135-154, (http://emeraldinsight.com/doi/full/10.1108/ET-09-2014-0122), diakses 11 Mei 2017.

Ojala, A. 2016. Discovering and Creating Bussiness Opportunities for Cloud Service. Journal of System and Software, (Online), 113: 408-417, (http://www.sciencedirect.com/science/article/pii/S0164121215002393), diakses 11 Mei 2017.

Pruett, M \& Sesen, H. 2017. Faculty Student Perceptions About Entrepreneurship in Six Countries. Education+Training, (Online), 59 (1): 105-120, (http://emeraldinsight.com/doi/full/10.1108/ET-03-2013-0028), diakses 11 Mei 2017.

Seuneke, P. 2015. Exploring The Roles of Women in The Development of Multifunctional Entrepreneurship on Family Farms: An Entrepreneurial Learning Approach. NJAS-Wageningen Journal of Life Sciences, (Online), 7475: 41-50, (http://www.sciencedirect.com/science/article/pii/S1573521415000159), diakses 11 Mei 2017. 
Soemanto, W. 2008. Pendidikan Wiraswasta. Jakarta: Bumi Aksara.

Sugiyono. 2013. Memahami Penelitian Kualitatif. Bandung: Alfabeta.

Sugiyono. 2013. Metode Penelitian Pendidikan. Bandung: Alfabeta.

Sutanto, A. 2002. Kewirausahaan. Jakarta: Ghalia Indonesia.

Suryana. 2013. Kewirausahaan Kiat Proses Menuju Sukses. Jakarta: Salemba Empat.

Sutopo. 2006. Metodologi Penelitian Kualitatif. Surakarta: UNS.

Kasmir. 2006. Kewirausahaan. Jakarta: PT Raja Grafindo Persada.

Katz, J.A. 2001. The Logic and Opportunities of Secondary Analysis in Entrepreneurship Research. Book Series: Advances in Entrepreneurship, Firm Emergence Growth, (Online), 4: 5-29, ((http://emeraldinsight.com/doi/pdfplus/10.1016/S10747540\%2800\%2904002-2), diakses 11 Mei 2017.

Moleong, L.J. 2012. Metodologi Penelitian Kualitatif. Bandung: PT Remaja Rosdakarya.

Robinson, S., Neegaard, H., Tenggaard, L \& Krueger, N.F. 2016. New Horizons in Entrepreneurship Education: From Teacher-Led to Student-Centered Learning. Education+Training, (Online), 58 (7): 661-683, (http://emeraldinsight.com/doi/full/10.1108/ET-03-2016-0048), diakses 11 Mei 2017.

Rofiah, C. 2016. Pengaruh Konsep Diri dan Lingkungan Sekolah Terhadap Minat Berwirausaha. Jurnal Hasil Riset, (Online), 2 (1): 1-11, (http://www.ejurnal.com/2016/03/pengaruh-konsep-diri-dan-lingkungan.html), diakses 25 November 2016.

Rusdiana, A . 2014. Kewirausahaan Teori dan Praktik. Bandung: Pustaka Setia.

Shirokova, G., Osiyevskyy, O., Bogatyreva, K. 2016. Exploring the intention Behavior Link in Student Entrepreneurship: Moderating Effect of Individual and Environmental Characteristics. European Management Journal, (Online), 34 (4): 386-399, (http://www.sciencedirect.com/science/article/pii/S0263237315001310), diakses 11 Mei 2017.

Stamboulis, Y., Barlas, A. 2014. Entrepreneurship Education Impact on Student Attitudes. The International Journal of Management Education, (Online), 12 (3): 365-373, 
http://www.sciencedirect.com/science/article/pii/S1472811714000421), diakses 11 Mei 2017.

Triyani. 2016. Pengaruh lingkungan keluarga dan Pembelajaran Kewirausahaan Terhadap Minat Berwirausaha Siswa Kelas X Program Keahlian Pemasaran SMKN 2 Blitar. Skripsi tidak diterbitkan. Malang: Universitas Negeri Malang.

Walter, S., Block, J. 2015. Outcomes of Entrepreneurship Education: An Institutional Perspective. Journal of Business Venturing, (Online), 31 (2): 216233, (http://www.sciencedirect.com/science/article/pii/S088390261500066X), diakses 11 Mei 2017.

Winarno, A. 2010. Pendidikan Kewirausahaan Berbasis Nilai. Surabaya: Putra Media Nusantara.

Winarno, A. 2015. Model Pendidikan Kewirausahaan Adaptasi Kurikulum 2013 bagi SMK (Deskriptif Persiapan dan Hambatan Penerapan di Sekolah. Jurnal Pendidikan Bisnis \& Manajemen, 1 (1): 1-10. Malang: Jurusan Manajemen Fakultas Ekonomi Universitas Negeri Malang.

Woodfield, P., Woods, C., Shepherd, D. 2011. Suinstainable Entrepreneurship: Another Avenue for Family Bussiness Scholarship. Journal of Family Business Management, (Online), 7 (1): 122-132, (http://emeraldinsight.com/doi/full/10.1108/JFBM-12-2015-0040), diakses 11 Mei 2017.

Zampetakis, L.A., Kafetsios, K., Moustakis, V. 2017. Using Emotional Persuasion for Changing Attitudes Toward Entrepreneurship: An Interpersona; Perspective. Journal of Business Venturing Insight, (Online), 7: 50-54, (http://www.sciencedirect.com/science/article/pii/S2352673416300415), diakses 11 Mei 2017.2013 bagi SMK (Deskriptif Persiapan dan Hambatan Penerapan di Sekolah. Jurnal Pendidikan Bisnis \& Manajemen, 1 (1): 1-10. Malang: Jurusan Manajemen Fakultas Ekonomi Universitas Negeri Malang.

Woodfield, P., Woods, C., Shepherd, D. 2011. Suinstainable Entrepreneurship: Another Avenue for Family Bussiness Scholarship. Journal of Family Business Management, (Online), 7 (1): 122-132, (http://emeraldinsight.com/doi/full/10.1108/JFBM-12-2015-0040), diakses 11 Mei 2017.

Zampetakis, L.A., Kafetsios, K., Moustakis, V. 2017. Using Emotional Persuasion for Changing Attitudes Toward Entrepreneurship: An Interpersona; Perspective. Journal of Business Venturing Insight, (Online), 7: 50-54, (http://www.sciencedirect.com/science/article/pii/S2352673416300415), diakses 11 Mei 2017. 